\title{
Risks associated with dispersive nocturnal flights of sylvatic Triatominae to artificial lights in a model house in the northeastern plains of Colombia
}

David Jácome-Pinilla ${ }^{1}$, Eduwin Hincapie-Peñaloza², Mario I. Ortiz' ${ }^{1}$ Juan David Ramírez ${ }^{3}$, Felipe Guhl ${ }^{1}$ and Jorge Molina ${ }^{1,4^{*}}$

\begin{abstract}
Background: Control initiatives and continuous surveillance of vector-borne transmission have proved to be effective measures for diminishing the incidence of Chagas disease in endemic countries. However, the active dispersal of infected sylvatic adult triatomines by flight represents one of the main obstacles to eliminating domestic transmission.
\end{abstract}

Methods: In order to determine the risk that active dispersal of sylvatic adult triatomines represents in Colombian northeastern plains, we quantified the distribution and abundance of triatomines in palm trees (primarily Attalea butyracea) using live bait traps. Directional light traps were used to estimate the frequency of sylvatic triatomine dispersal and their possible origin. Finally, the effect of environmental parameters and artificial light sources on the take-off of sylvatic Rhodnius prolixus was evaluated in field experiments.

Results: $R$. prolixus was found in $90 \%$ of the palm trees that densely aggregated toward the northern portion of the study area. $R$. prolixus, and three other sylvatic triatomine species were found to actively disperse and were attracted to the directional light traps (Triatoma maculata, Panstrongylus geniculatus and Psammolestes arthuri). Temperature, relative humidity, wind speed and night luminosity did not affect the active dispersal of the triatomines which is higher the first two hours after sunset. Artificial lights from houses at 60 and $110 \mathrm{~m}$ played a key role in the directionality of the $R$. prolixus take-offs. Trypanosoma cruzi was isolated from R. prolixus, T. maculata and P. geniculatus and was genotyped as T. cruzi I, III and IV.

Conclusions: Our results highlight the potential risk in Colombian northeastern plains of actively dispersing sylvatic triatomines and their role in the domestic introduction of Discrete Typing Units of T. cruzi associated to sylvatic foci of Chagas disease transmission.

Keywords: Rhodnius prolixus, Trypanosoma cruzi, Chagas disease, Palm trees, Active dispersal, Light trap, Flight initiation

\footnotetext{
* Correspondence: jmolina@uniandes.edu.co

${ }^{1}$ Centro de Investigaciones en Microbiología y Parasitología Tropical

(CIMPAT), Departamento de Ciencias Biológicas, Universidad de los Andes,

Bogotá, Colombia

${ }^{4}$ Facultad de Ciencias, Universidad de los Andes, A.A. 4976 Carrera 1a \#

18A-10, Bogotá, Colombia

Full list of author information is available at the end of the article
}

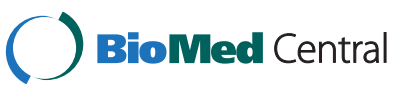

(C) 2015 Jácome-Pinilla et al. Open Access This article is distributed under the terms of the Creative Commons Attribution 4.0 International License (http://creativecommons.org/licenses/by/4.0/), which permits unrestricted use, distribution, and reproduction in any medium, provided you give appropriate credit to the original author(s) and the source, provide a link to the Creative Commons license, and indicate if changes were made. The Creative Commons Public Domain Dedication waiver (http://creativecommons.org/publicdomain/zero/1.0/) applies to the data made available in this article, unless otherwise stated. 


\section{Background}

Chagas disease, caused by Trypanosoma (Schyzotrypanum) cruzi Chagas 1909, is a current public health problem in the Americas, with nearly 28 million people at risk of infection, 12,500 annual deaths and 41,200 new human cases each year due to vector transmission $[1,2]$. This parasite displays remarkable genetic diversity as evidenced by at least six discrete typing units (DTUs). Intriguingly, the distribution of these DTUs is associated with domestic and sylvatic foci; TcI, TcII, TcV and TcVI are associated with the domestic cycle, and TcI, TcIII and TcIV are associated with sylvatic foci with sporadic cases in humans [3]. Triatomine bugs (Reduviidae: Triatominae), which are highly anthropophilic and are capable of establishing permanent colonies in human dwellings, are considered to be the vectors of T. cruzi $[1,4]$.

In Colombia, nearly a quarter of the population is at risk for Trypanosoma cruzi infection, and approximately $7 \%$ are infected with the parasite [5]. Most of the vectorial transmission in Colombia is attributed to Rhodnius prolixus Stål 1859, because of its wide geographical distribution and its presence in domestic, peridomestic and sylvatic (associated with Attalea spp. and Elaeis spp. palm trees) habitats [5].

Strategies to control Chagas disease in Latin America have been based on the interruption of vector transmission by eliminating domestic insect populations with residual insecticides [6, 7]. However, several problems have emerged that have prevented a complete reduction in vectorial Chagas transmission, including the re-infestation of houses by sylvatic and peridomestic triatomines [8-11], colonization and re-infestation by species of triatomines that are considered to be secondary vectors [12-15] and the re-establishment of residual populations that were not entirely eliminated by chemical treatments [16].

Laboratory [17-19] and field studies [12, 13, 20-24] have proved the importance of sylvatic/peridomestic flying triatomine adults in the infestation and re-infestation of houses, except for a few cases reported with Triatoma infestans Klug 1834 [25, 26].

The role of artificial light sources in the attraction of actively dispersing triatomines has been tested [12, 13, 21, 27-33]. In addition to light, nutritional status, feeding rates during metamorphosis of the insects, environmental temperature and dimorphism of flight-related muscles have all been recognized for their roles in active dispersal $[12,17,20,21,23,27,30,34-40]$.

The relevance of active triatomine dispersal to Chagas disease transmission has led a committee of experts to recommend studies in Colombian and Venezuelan grassland plains in order to determine the epidemiological risk that sylvatic populations of $R$. prolixus represent in those areas [1]. In Colombia, the relevance of sylvatic triatomine species in Casanare and Arauca plains has recently been highlighted by the finding that $R$. prolixus, Psammolestes arthuri (Pinto, 1926), Cavernicola pilosa (Barber 1937), Triatoma maculata (Erichson, 1848) and Panstrongylus geniculatus (Latreille, 1811) are reaching human dwellings [41]. Due to this plethora of events, the aim of this study was to characterize the active flight dispersal of sylvatic triatomines in a typical house in Casanare grassland plains using two approaches: i) First, we quantified the presence and abundance of triatomines in palm trees around a house in the region. ii) Second, we quantified the number of triatomines that appeared to be attracted to light sources and to the house, and we attempted to correlate the flight dispersal with environmental parameters. Finally, we quantified the attractiveness of artificial light bulbs in take-off experiments with sylvatic $R$. prolixus that had previously been captured during active dispersal.

\section{Methods}

Study area and palm tree sampling

Fieldwork was carried out in Paz de Ariporo Municipality (Casanare) in northeast Colombia ( $5^{\circ} 50^{\prime} 19^{\prime \prime} \mathrm{N}, 71^{\circ}$ 53' 31"W and 360 m.a.s.l.). Prevalence of Chagas disease in Paz de Ariporo Municipality is 14.75 \% considering both urban and rural areas, but in rural areas the prevalence is $22.22 \%$ for females and $14.81 \%$ for males [42]. The study area consisted of a house surrounded to the north by grassland plains with dispersed palm trees and gallery forests along the Muese river and to the south by grassland plains with few palm trees (Fig. 1). Ninety-four palm trees (eighty-eight Attalea butyracea (Mutis ex L.F.) Wess. Boer, five Acrocomia aculeata (Jacq.) Lood. ex Mart., and one Cocos nucifera Linnaeus) were sampled in the grassland plains around the house (Fig. 1). A modified live bait trap was used to capture triatomines in palm trees [43]. Each palm tree was sampled for one night with one live bait trap between 18:00 $\mathrm{h}$ and 6:00 $\mathrm{h}$ [44]. The geographical position of the palm tree and the number of insects, species, and nymphal stages captured were registered. All field work was carried out on private land with owners' permission.

\section{Directional light trap experiments}

Directional light traps modified from Sjogren and Ryckman (1966) were employed [27]. Each trap consisted of two white plastic "Black Out" panels $(1.20 \mathrm{~m} \times 1.00 \mathrm{~m})$. A frame with PVC pipes $(1.27 \mathrm{~cm}$ in diameter) and wood sustained both panels at right angles on a white plastic landing area $(1.40 \mathrm{~m} \times 2.00 \mathrm{~m})$. Three $100 \mathrm{Ws}$ incandescent light bulbs attached to a wooden strip $(0.8 \mathrm{~m} \times 0.1 \mathrm{~m})$ and facing inward were used as light sources (Fig. 2a). Two traps that were counterpoised and alternated between four directions (i.e., first night in NE and SW directions, next night NW and SE directions) to determine the dispersal rates and the approximate origins of the flying triatomines during thirty- 

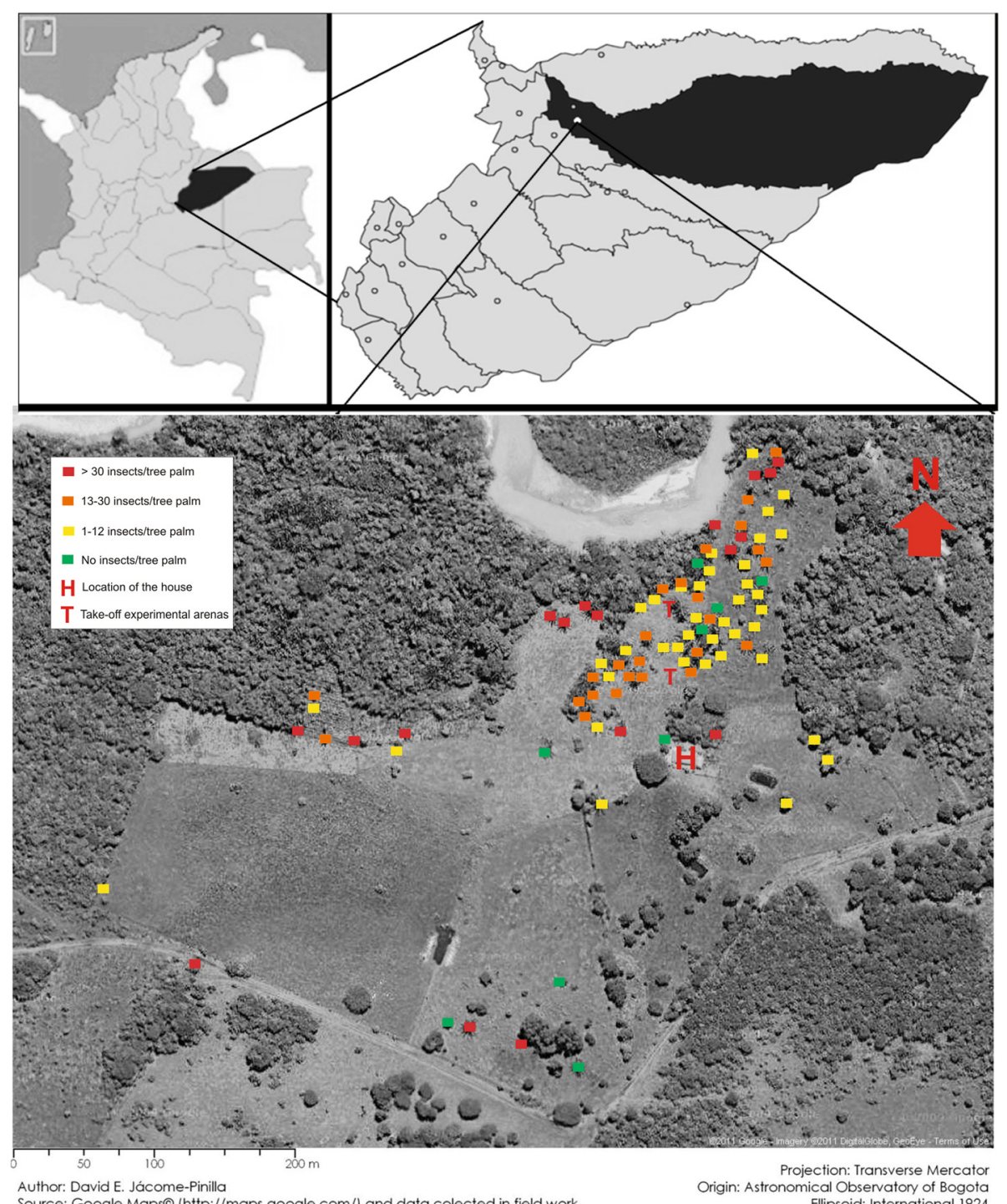

Fig. 1 Study area and abundance of triatomines in palm trees. Map of the location showing with colors the distribution and abundance of sylvatic triatomines in palm trees at Miramar farm in Paz de Ariporo (Casanare-Colombia). Satellite image from Google Maps ${ }^{\circledR}$

four consecutive nights. At the end, each one of the four directions was sampled with a directional trap for 17 nights. The panels and external walls of the house were revised every $15 \mathrm{~min}$ between 18:45 $\mathrm{h}$ and 00:30 h, resulting in a total of $102 \mathrm{~h} /$ light trap or $408 \mathrm{~h} /$ four light traps sampled.

Live bait and directional light traps were used simultaneously but always preventing interference between both sampling methods.

Insects attracted to the directional light traps were captured manually, identified following keys [4], and those identified as $R$. prolixus were used in later take-off experiments.

\section{Take-off experiments}

Two experimental arenas modified from Minoli and Lazzari (2006) were used [31]. Each arena was a $1 \mathrm{~m}^{3}$ tent made of black cloth and elevated $1 \mathrm{~m}$ above the ground by a PVC pipe $(1.27 \mathrm{~cm}$ in diameter $)$ frame (Fig. 2b). Cubic tents were always located to the north of the house at $60 \mathrm{~m}$ and $110 \mathrm{~m}$ (see "T" on Fig. 1). Inside each cubic tent was a take-off platform (Plexiglass dish $15 \mathrm{~cm}$ in diameter and $5 \mathrm{~cm}$ high with walls covered in Vaseline) that tested the nightly take-off directions of ten $R$. prolixus (five males and five females) that were marked individually with white body paint. The triatomines were only able to leave the take-off platform by flying from a circular piece of cardboard $(3 \mathrm{~cm}$ in diameter) marked with eight $45^{\circ}$ sectors. The behavior of $R$. prolixus in each cubic tent was recorded with a Genius IP Secure 300R infrared camera supported with a tripod (PVC pipes $1.27 \mathrm{~cm}$ in diameter) $15 \mathrm{~cm}$ above the take- 

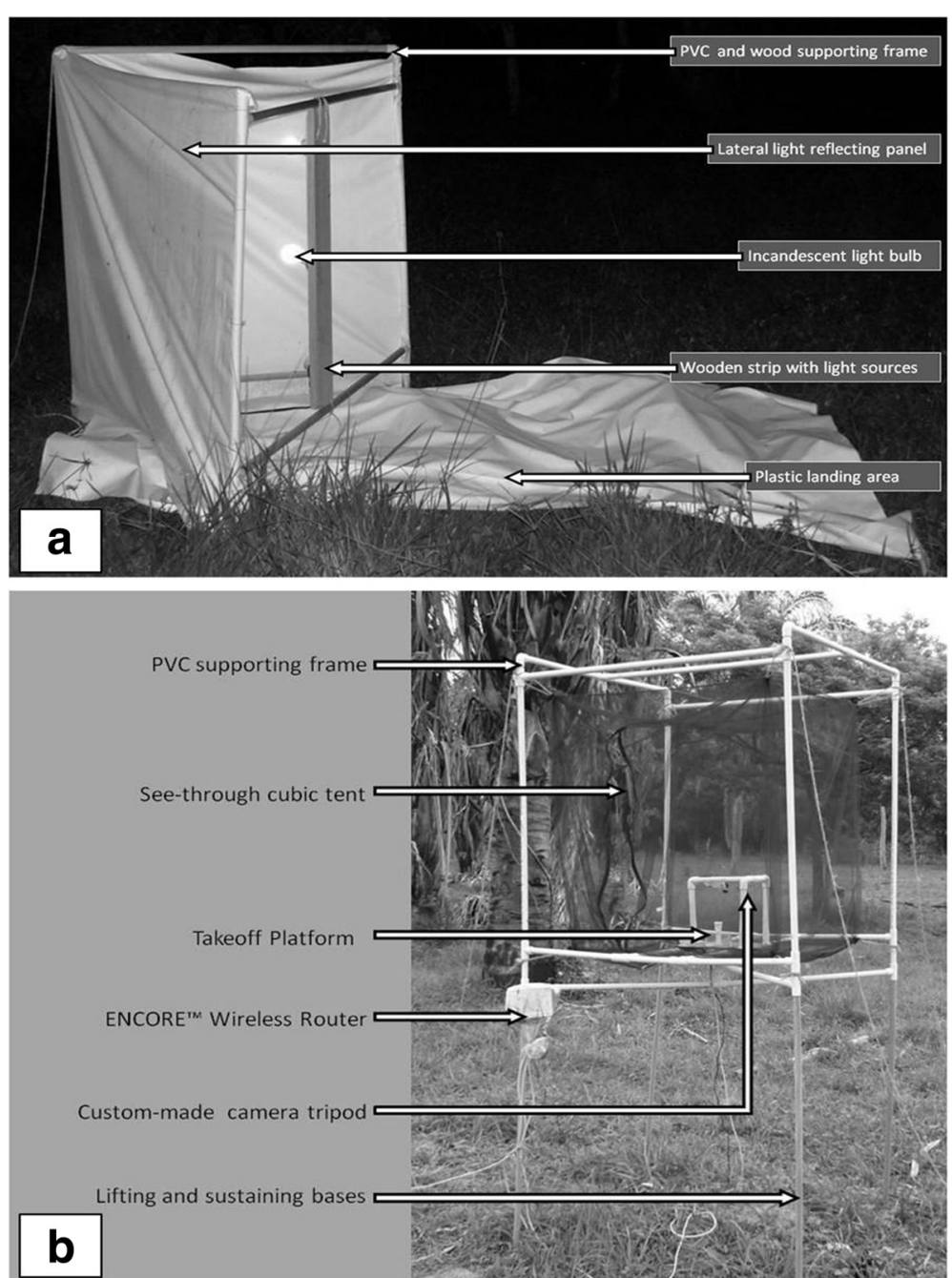

Fig. 2 Light traps and take-off arena used in the field experiments. a. Directional light traps (modified from Sjorgen \& Rickman (1966) [27]). b. Experimental cubical tent for take-off experiments (modified from Minoli \& Lazzari (2006) [31])

off platform (Fig. 2b). Each camera was connected to an Encore Electronics 802.11 g router and a Dell Inspirion 5100 computer by 5e Ethernet LAN cables. Lastly, realtime recordings of each platform were carried out during sixteen nights between 19:00 $\mathrm{h}$ and 00:30 $\mathrm{h}$ with two alternating light conditions (artificial light bulbs of the house facing to the cubic tents turned on or off). In total, eight nights for each experimental arena under each light condition were recorded. The time and takeoff sector were registered for each insect.

\section{Environmental parameters}

Temperature, relative humidity and wind velocity were recorded with data loggers (HOBO U23-001 and EXTECH AN400 respectively) every 15 min during all fieldwork nights at $12 \mathrm{~m}$ from the house and $2 \mathrm{~m}$ above the ground. Low values of environmental night luminosity and the light emitted by the artificial light bulbs of the house were measured manually every 15 min with a generic light dependent resistor (LDR) located $1.6 \mathrm{~m}$ above the ground, and $0.3 \mathrm{~m}$ away from the researcher. The LDR was connected to a multimeter (UNI$\mathrm{T}$ UT10A), and the results were later converted from Ohms $(\Omega)$ to LUX units using the correlation formula $y=$ $4 \times 10^{6} \times{ }^{-1.47}\left(\mathrm{R}^{2}=0.984\right)$. The formula was obtained at dusk during five consecutive days with measurements recorded simultaneously with the LDR-multimeter and a heavy duty light meter (EXTECK 407026).

Triatomine identification, determination of T. cruzi infection and DTU assignment

The captured sylvatic triatomines were identified using the keys of Lent and Wygodzinsky (1979) [4]. Rhodnius prolixus identifications were confirmed by analyzing DNA sequences of the cytochrome b gene [45]. Natural infection with $T$. cruzi was only assessed in the adults that were 
still alive after the fieldwork. The hindguts of twenty $R$. prolixus (eleven males, nine females) captured in palm trees, and twenty-six $R$. prolixus (twelve males, fourteen females), two $P$. geniculatus males and one $T$. maculata female captured with the directional light traps were examined with a light microscope. The positive feces were transferred to biphasic culture media for parasite isolation. When the isolate reached the logarithmic phase, aliquots of $200 \mu \mathrm{L}$ were subjected to DNA extraction using the miniprep Qiagen kit (Qiagen, Barcelona, Spain). The DTU assignment was performed using mitochondrial Multilocus Sequence Typing (MLSTmt) and Multilocus Microsatellite Typing (MLMT) using reference strains with previously established conditions [46].

\section{Data analysis}

ESRI ArcGIS v.9.3 was used to locate the sampled palm trees and the number of triatomines captured with the live bait traps from Google Maps images. KolmogorovSmirnov tests for normality were carried out. The effect of environmental parameters on the arrival of triatomines to the light traps was analyzed by linear regressions. Differences in the sex ratios and between the numbers of insects captured in each light trap were tested by the Mann-Whitney $U$ test and the KruskalWallis test, respectively. The Friedman test was used to compare the amount of light reaching each cubic tent with the two light conditions [47]. All the aforementioned statistical analyses utilized the SPSS v.16 software. The numbers of insects captured in the directional light traps were analyzed by the Kuiper and HodgesAjne test [48] that were calculated with the ORIANA v.3 (http://www.kovcomp.co.uk/oriana/) and Matlab v.8.3, R2014a (http://www.mathworks.com/products/matlab/) software. Friedman test was used to compare the number of insects that began flights at different time periods in the take-off experiments [47]. Take-off directions were analyzed by the Kuiper and Hodges-Ajne test [48] using ORIANA v.3 and Matlab v.8.3, R2014a software.

\section{Results}

Palm tree sampling, infestation map and $T$. cruzi infection Four sylvatic species (2169 insects: 2039 in palm trees and 130 actively dispersing) were collected during our field work: Panstrongylus geniculatus (0.32\%), Psammolestes arthuri $(0.18 \%)$, Triatoma maculata $(0.28 \%)$ and Rhodnius prolixus (99.22\%). Most of our results will refer to $R$. prolixus because of its increased abundance over the other triatomine species. Higher concentrations of palm trees with triatomine infestations were found to the north of the house (Fig. 1). Of the ninety-four palm trees sampled, only nine $(9.6 \%)$ were negative for triatomines (six A. butyracea, two A. aculeata and one C. nucifera). R. prolixus was the most abundant species with 2034 insects captured in palm trees (543 nymphs I (NI), 610 NII, 441 NIII, 183 NIV, 179 NV, 34 males and 44 females). The number of insects captured ranged from one insect/night in five palm trees to 246 insects/night in another palm tree. The mean value and range of the different stages of $R$. prolixus captured per palm tree are shown in Table 1. In addition to $R$. prolixus, $T$. maculata individuals were also captured in palm trees (five NII in two A. aculeata and two $A$. butyracea). Eleven males and nine females were dissected and examined microscopically in the hindgut, of these, three $R$. prolixus (two males and one female) were found to be positive for T. cruzi (15\%).

\section{Directional light trap experiments and $T$. cruzi infection}

One hundred and thirty triatomines were captured with the directional light traps. One hundred and eighteen were identified as $R$. prolixus (59 males and 59 females), seven as $P$. geniculatus (six males and one female), four as Ps. arthuri (one male, two females and one not determined), and one female as T. maculata. Considering only $R$. prolixus, in average 6.9 insects/night and 3.47 insects/directional light trap were captured.

While the female T. maculata was captured on the trap facing NE, the other three species were captured on the traps that faced all four directions sampled. Kuiper's test showed that our data were not following the von Mises distribution $(K>K(\alpha))$ [46]. The traps facing to the NE and NW attracted directionally $R$. prolixus (Hodges-Ajne test, $p<\mathrm{p}(\alpha))$ (Fig. 3).

The majority of $R$. prolixus (58.47 \%) arrived within the first two hours of sampling (Kruskal-Wallis test, $p=0.014$ ) (Fig. 4), and the maximum number of insects captured in one hour was eleven. No significant relationships were found between captures and the environmental parameters measured (Table 2) (temperature $R^{2}<0.001, p=0.895$; relative humidity $R^{2}=0.015, p=0.481$; wind speed $R^{2}=0.024$, $p=0.452$ and night luminosity $R^{2}=0.083, p=0.122$ ). The probability of capturing an actively dispersing triatomine on a given night under the range of environmental parameters measured was 0.74 . This value was higher during the first two hours after sunset and progressively decreased

Table 1 Mean and range of the different stages of Rhodnius prolixus captured with live bait in the 94 palm trees in Miramar farm (Paz de Ariporo-Casanare)

\begin{tabular}{lllll}
\hline Stage & Mean & Minimum & Maximum & St.Dev \\
\hline N I & 8.35 & 1 & 80 & 15.4 \\
N II & 9.24 & 1 & 97 & 14.7 \\
N III & 5.96 & 1 & 42 & 7.6 \\
N IV & 3.59 & 1 & 14 & 3.4 \\
N V & 4.26 & 1 & 34 & 5.5 \\
Male & 1.62 & 1 & 3 & 0.7 \\
Female & 1.57 & 1 & 4 & 0.8 \\
\hline
\end{tabular}




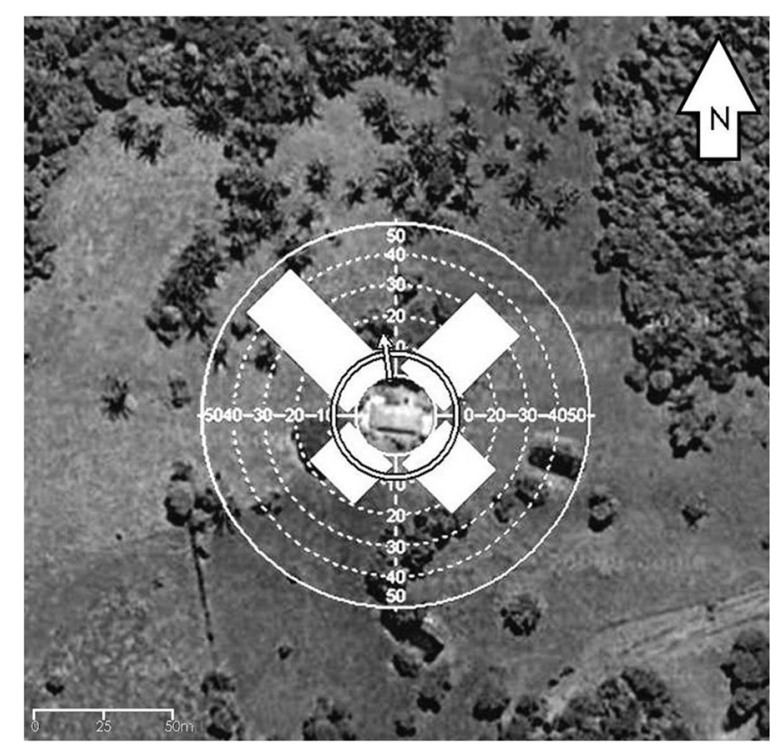

Fig. 3 Source of flying Rhodnius prolixus captured with directional light traps. Histograms with numbers of $R$. prolixus captured with directional light traps facing to the NW, NE, SW, and SE. White arrow is the mean vector ( $N=118$ insects, $\mu=351.47^{\circ}$ and $\left.r=0.269\right)$. Satellite image from Google Maps ${ }^{\circledast}$

throughout the night (Fig. 4). No walking nymphs were found to reach the plastic landing area of the directional light traps.

None of the twenty-six dissected $R$. prolixus (twelve males and fourteen females) were found with $T$. cruzi, and only two males of P. geniculatus and one female of T. maculata were found to be infected with the parasite.

\section{Molecular characterization of $T$. cruzi infections}

We obtained two isolates from $R$. prolixus captured in palm trees; two from $P$. geniculatus and one from $T$. maculata captured with the directional traps. The isolates were cloned, and ten biological clones were obtained from each isolate. The results of the high-resolution molecular characterization of the 20 clones from P. geniculatus demonstrated the occurrence of mixed infections of $\mathrm{TcI}$ (55\%), TcIII (30\%) and TcIV (15\%). In the case of R. prolixus and T. maculata, all the clones were typed as TcI with a peculiar tailored allelic profile. In phylogenetic reconstructions (data not shown), these clones clustered in a basal clade that was tightly related to the sylvatic isolates obtained from Alouatta seniculus (Linnaeus 1766). Those clones identified as TcI were subsequently analyzed by SLIR, where the presence of TcId was observed (genotype associated to the sylvatic cycle).

\section{Attraction of R. prolixus to external lights for the house}

The search for triatomines on the exterior walls of the house yielded an additional $31 R$. prolixus (17 males and 14 females), two males of $P$. geniculatus and one male of Ps. arthuri. No walking nymphs were found to reach the exterior walls of the house during the sampling.

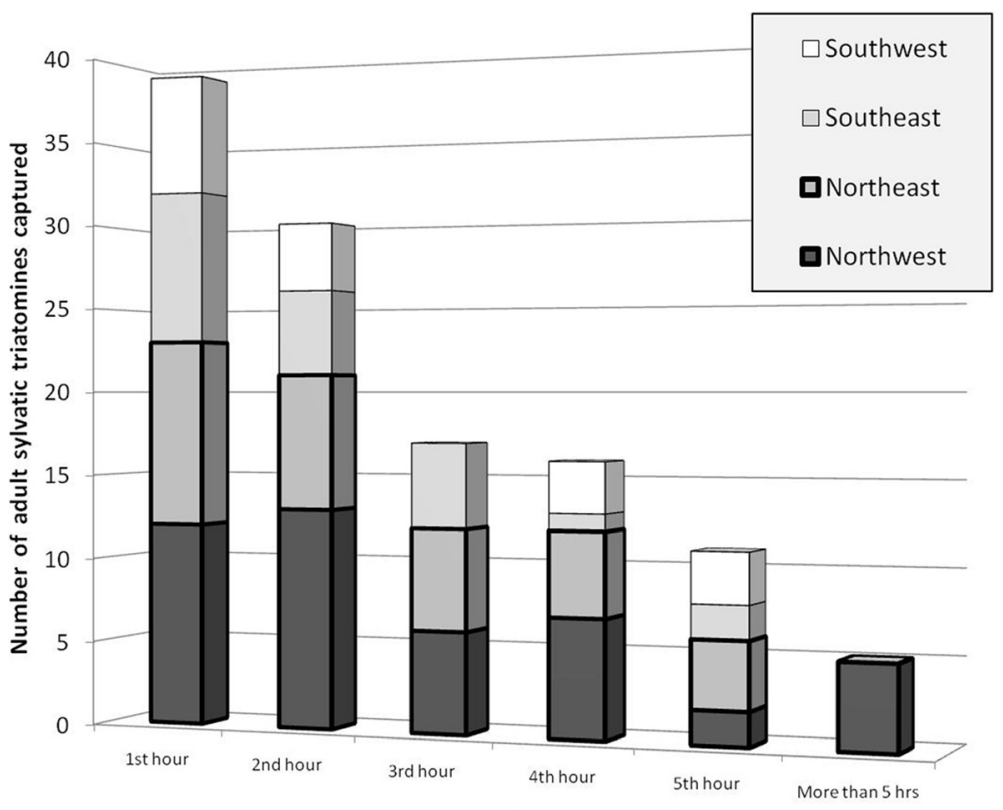

Time after activating the directional light traps

Fig. 4 Number of actively dispersing triatomines captured with directional light traps. Histograms with numbers of R. prolixus captured per hour after dusk on the directional light traps facing to the NW, NE, SW, and SE 
Table 2 Mean, maximum and minimum values of environmental variables recorded during 34 nights in Casanare-Colombia

\begin{tabular}{llrccc}
\hline Variable & & Mean & Minimum & - & Maximum \\
\hline Temperature & $\left({ }^{\circ} \mathrm{C}\right)$ & 26.17 & 23.1 & - & 29.6 \\
Relative Humidity & $(\%)$ & 81.02 & 51.4 & - & 98.4 \\
Wind Speed & $(\mathrm{m} / \mathrm{s})$ & 0.11 & 0.0 & - & 0.6 \\
Luminosity & $(\mu \mathrm{LUX})$ & 74.16 & $26.15^{\mathrm{a}}$ & - & $8031.01^{\mathrm{b}}$ \\
\hline
\end{tabular}

${ }^{a}$ Moonless dark night

${ }^{\mathrm{b}}$ Cloudless and full moon night

\section{Take-off experiments with R. prolixus}

On average, $6.5 R$. prolixus per night initiated flights in each experimental arena. However, the majority (77 \%) tended to start flights within the first half hour of the experiments (Friedman test, $p=0.001$ ). The take-off by $R$. prolixus was dependent of the natural light conditions and distances of the cubic tents (Friedman test, $p=0.02$ ) (Table 3). Both sexes started their flights in similar numbers (MannWhitney $\mathrm{U}$ test, $p=0.087$ ). Take-offs were non directional when the artificial lights of the house were turned off (Hodges-Ajne test, $p>\alpha$ cubical tent at $60 \mathrm{~m}$ and $110 \mathrm{~m})$. However, directionality to the house $\left(0^{\circ}\right.$ in Fig. 5$)$ was found when the lights were turned on (Hodges-Ajne test, $p<\alpha$ cubical tent at $60 \mathrm{~m}$ and $110 \mathrm{~m}$ ).

\section{Discussion}

The above results, and those reported by Angulo et al. (2012) and Rendon et al. (2015) [41, 49], confirm the relevance of active dispersal by sylvatic triatomines in Colombian and Venezuelan grassland plains, which has been highlighted by a committee of experts [1].

Casanare Department encompasses an area of $44,500 \mathrm{~km}^{2}$ with a very low population density $\left(7.44\right.$ persons $\left./ \mathrm{km}^{2}\right)$ dispersed in rural areas [50]. In rural areas, people usually live in very similar settings: few isolated houses surrounded by palm trees of Attalea butyracea [44, 49, 50]. Two advantages were considered for sampling the model house in the present study: Firstly, a high concentration of palm trees to the north side of the house and the presence of a grassland space in between that allowed us to carry out the take-off experiments. Secondly, since the nearest house in the area was located not closer than one $\mathrm{km}$ away, we could be certain that no other chemical and visual stimuli from nearly houses interfered with our experiments.

Table 3 Average amount of light reaching the take-off experimental arenas under the two light conditions

\begin{tabular}{llc}
\hline $\begin{array}{l}\text { Light } \\
\text { Condition }\end{array}$ & $\begin{array}{l}\text { Distance From } \\
\text { the House }(m)\end{array}$ & $\begin{array}{l}\text { Average Light From } \\
\text { the House* }(\mu L U X)\end{array}$ \\
\hline ON & 60 & 2237.28 \\
& 110 & 169.68 \\
OFF & 60 & 79.43 \\
& 110 & 40.51 \\
\hline
\end{tabular}

*Friedman test showed statistically significant differences $(p=0.02)$
Similar results considering sylvatic dispersion of triatomines could be expected in other municipalities of Casanare considering the above mentioned distribution of the rural population, the similarity in the ecological conditions of the rural areas in the Department [50], and the high prevalence of Trypanosoma cruzi infection in Casanare [42].

However, some questions remain to be investigated in Casanare considering potential effects on the attraction of triatomines to artificial light sources. For instance: what will be the effect of several houses together with artificial light sources of different intensities? How would the outcome of the experiments change if tree palms surround houses in closer proximity? And, what should be expected if $A$. butyracea natural forest is replaced by oil tree palm plantations surrounding the houses?

All four sylvatic species of triatomines captured here have been previously reported in Colombian northeastern plains and are associated with sylvatic habitats in Ecuador, Brazil and other South American countries [4, 5, 51, 52]. These species can be divided into three groups based on their risk of domiciliation: Rhodnius prolixus and T. maculata are frequently domiciliated in Colombia [5], P. geniculatus is highly associated with burrows of mammals, tree bark, palm trees and bat caves [4] as well as several domiciliated populations in Colombia and Venezuela [53, 54], and, finally, Ps. arthuri which has only been reported in sylvatic niches associated with bird nests, palm trees and the bark of dead trees [4].

Our live bait traps mainly captured $R$. prolixus in palm trees, confirming that $A$. butyracea is a relevant sylvatic niche for $R$. prolixus $[5,41,49]$. Furthermore, the presence $R$. prolixus infected with T. cruzi (TcId genotype) in palm trees highlights this active focus of sylvatic T. cruzi transmission that is widely distributed in Colombian northeastern plains [5]. Likewise, molecular epidemiology studies in the area have identified T. cruzi sylvatic genotypes in $R$. prolixus captured in Attalea palms, suggesting that these triatomines represent a high risk factor when invading domestic foci $[11,46,55]$. Moreover, different cohort studies have incriminated T. cruzi sylvatic genotypes in cardiomyopathies of chronic patients from Argentina and Colombia [56, 57].

Our results of actively dispersing triatomines infected with $T$. cruzi also show that sylvatic Chagas disease transmission can take place with the aid of P. geniculatus in the region. We obtained mixed infections of DTUs in the captured P. geniculatus specimens. The DTUs herein reported (TcI, TcIII and TcIV) are closely related to the sylvatic cycle of parasite transmission. The transmission dynamics of these genotypes is maintained by sylvatic reservoirs, such as Alouatta seniculus, Philander frenata (Olfers 1818), Monodelphis brevicaudata (Erxleben 1777) and Dasypus novemcinctus Linnaeus 1758 [51]. 


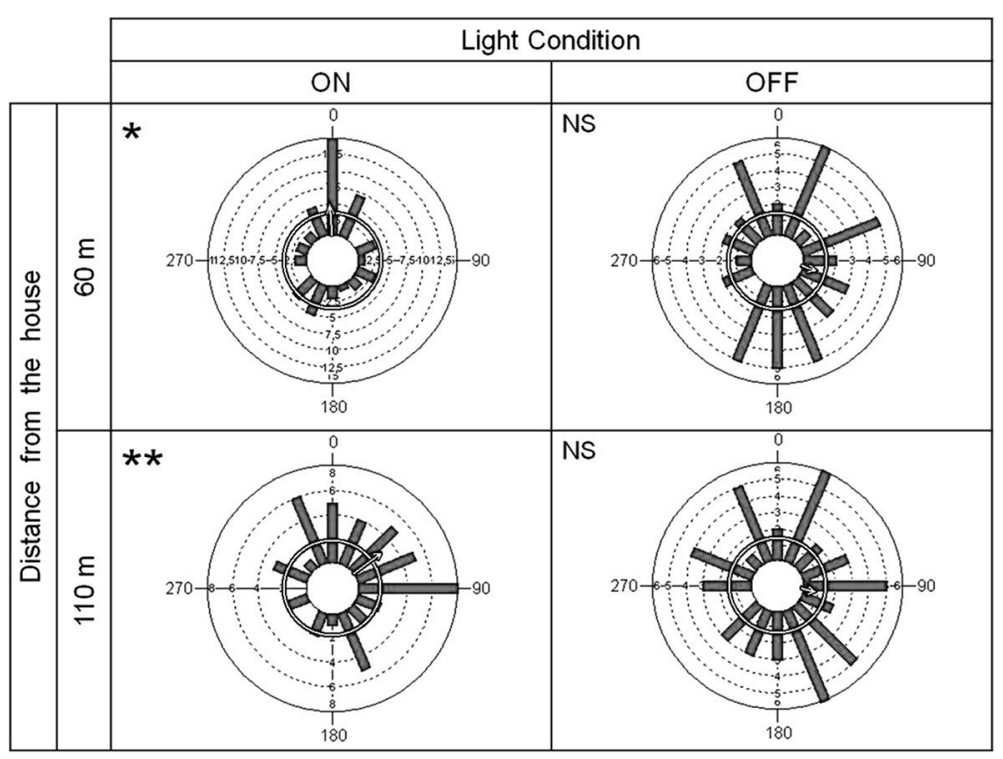

Fig. 5 Take-off directions of sylvatic Rhodnius prolixus. Histograms with the total numbers of flying $R$. prolixus under field conditions with lights turned on or off. Mean vectors: with light bulbs turned on and at $60 \mathrm{~m} \mu=356.88^{\circ}, r=0.306$ and at $110 \mathrm{~m} \mu=52.44^{\circ}, r=0.358$; with light bulbs turned off and at $60 \mathrm{~m} \mu=101.41^{\circ}, r=0.135$ and at $110 \mathrm{~m} \mu=96.72^{\circ}, r=0.125$. Asterisks indicates directionality to the house (set at $\left.0^{\circ}\right)$ (Hodges-Ajne test, $p<p(a)$ ). NS = not significant

The presence of T. cruzi DTUs associated with the sylvatic cycles could increase the probability of new symptomatic cases of Chagas disease in the region. This unorthodox assumption is supported by the findings of TcIII and TcIV in Colombian cardiomyopathic patients where P. geniculatus insects have been captured [57]. Additionally, the occurrence of this DTU has been attributed to the emergence of Chagas disease in Venezuela and Bolivia, as vectored by $P$. geniculatus and T. infestans, respectively [58, 59].

The high concentration of palm trees with triatomines to the north of the house (Fig. 1) explains the results obtained with the directional light traps. The traps facing to the NE and NW attracted significantly more actively dispersing $R$. prolixus adults than the traps facing to the south (Fig. 3). Field experiments carried out with triatomines suggest that they are able to fly the distances between palm trees, directional light traps and the house [13, 20-23, 28]. The detection of the TcId genotype in $R$. prolixus, which is related to sylvatic habitats, corroborates the notion that the specimens approaching the house initially inhabited the sylvatic niche. The presence of $R$. prolixus infected with sylvatic T. cruzi genotypes in palm trees has been previously observed in the Venezuelan grassland plains [60].

To confirm the effect of artificial white light sources [31] on the directionality of active dispersal, we carried out take-off experiments. Our field experiments showing that sylvatic $R$. prolixus of both sexes were induced to fly in response to white light confirmed the importance of artificial white lights for take-off even at $110 \mathrm{~m}$ of distance (Table 3 and Fig. 5). The distances tested in our experiments were in the range of the reported flightdispersal capacity of Triatoma infestans [8, 21, 23], suggesting that palm trees located within that radius should be specially regarded following insecticide application in order to reduce colonization or re-colonization. The results herein reported, along with the wide distribution of Attalea butyracea in Casanare, could partially explain why $18 \%$ of the houses in Casanare reported re-infestation with Rhodnius spp. five months after applying residual insecticides during 2004 and 2005 campaigns [61].

The absence of a correlation between the environmental parameters measured in this study (Table 2) and the high flight dispersals suggests that climatic stability in the grassland plains of Colombia and Venezuela should promote dispersal rates similar to those reported throughout the year, only with a reduction in dispersal on days with heavy rainfall during the day or prior to sunset [27, 32, 33]. In those cases, temperatures below $20^{\circ} \mathrm{C}$ or strong air movements in the initial hours after dark will negatively affect triatomine flights [30].

Our findings of actively dispersing $P$. geniculatus and Ps. arthuri highlight the importance of other sylvatic species in future control measures against domiciliated triatomines in Colombian northeastern plains. Control measures in Brazil have highlighted the importance of sporadic or progressive invasions of human dwellings by triatomine species that are considered to be secondary vectors after the elimination of the primary vector species [15]. P. geniculatus is recognized for its attraction to 
artificial lights $[4,33]$, its relationship with $T$. cruzi reservoirs, such as armadillos [4], its infection with $T$. cruzi and its potential risk of domiciliation [53, 54]. The attraction of Ps. arthuri to artificial light sources (directional light traps and lighted walls of the house) confirms the findings reported by Angulo et al. (2012) [41] and suggests the attraction to artificial lights of sylvatic species naturally infected with $T$. cruzi even though they are associated to bird nests [4].

Although low numbers of $P$. geniculatus and T. maculata were captured in our study, it is important to highlight the infection rates with $T$. cruzi found in both species ( 2 of 7 individuals of $P$. geniculatus and 1 of 1 of T. maculata). Both species should be carefully considered by health authorities for maintaining Chagas Trypanosoma cruzi circulation in Casanare, as has been shown in other areas of Colombia [62-64].

The relevance of our findings is highlighted by the acute oral outbreak of Chagas disease that occurred recently in the town of Paz Ariporo (located at approximately $4 \mathrm{Km}$ of our field study area), affecting 31 workers from companies linked to the mining sector who were exposed to food contaminated with either traces or the feces of infected triatomines [49].

How can our results help to reduce the active dispersal of sylvatic triatomines in grassland plains ecosystems? One recommendation is that external artificial lights on walls remain turned off for the first hours after sunset, which is when most sylvatic triatomines find favorable atmospheric and environmental conditions for dispersal (Fig. 4). It has previously been reported that triatomines are captured at higher rates within the first hours after sunset [12, 17, 27, 30]. This recommendation, which sounds very promising, should be tested by an 'adaptive management' strategy to see if this policy would be effective in practice.

\section{Conclusions}

Our results using a model house from the northeastern Colombian plains confirm that four triatomine species (Rhodnius prolixus, Triatoma maculata, Psammolestes arthuri and Panstrongylus geniculatus) are actively dispersing in the area and that they are highly attracted to artificial lights. Furthermore, the environmental parameters encountered during this study, particularly during the first hours after sunset, are favorable for the active dispersal of sylvatic triatomines. Finally, sylvatic $R$. prolixus initiates flight independently of sex, night luminosity, and the quantity of artificial light. However, the directionality of the take-offs is determined by the artificial light stimuli and the distance to its source. Our results suggest that the absence of systematic surveillance of dispersing sylvatic triatomines in Colombian grassland plains leads to underestimates of the risk that these species represent for chemical control campaigns and for the introduction of sylvatic T. cruzi DTUs into the domestic environment. The increasing likelihood that sylvatic DTUs influence the development of cardiomyopathy highlights the need to pursue further studies in the region aimed at establishing robust surveillance programs. Such programs will hopefully prevent the emergence of secondary Chagas disease vectors in Colombia.

\section{Abbreviations}

cm: centimeter; DTUs: discrete typing units; h: hour; km: Kilometers; LDR: light dependent resistor; m: meter; m.a.s.l.: meters above sea level; MLMT: Multilocus Microsatellite Typing; MLSTmt: mitochondrial Multilocus Sequence Typing; N: North; NE: Northeast; NI: first instar nymphs; NII: second instar nymphs; NIII: third instar nymphs; NIV: fourth instar nymphs; NV: fifth instar nymphs; NW: Northwest; SE: Southeast; SL-IR: Spliced Leader Intergenic Region; SW: Southwest; Tcl: Trypanosoma cruzi Discrete Typing Unit 1 I; Tcll: Trypanosoma cruzi Discrete Typing Unit 2 Il; Tclll: Trypanosoma cruzi Discrete Typing Unit 3 III; TcIV: Trypanosoma cruzi Discrete Typing Unit 4 IV; TcV: Trypanosoma cruzi Discrete Typing Unit 5 V; TcVl: Trypanosoma cruzi Discrete Typing Unit 6 Vl; Ws: Watts; W: West; $\mu \mathrm{L}$ : microliter.

\section{Competing interests}

The authors declare that they have no competing interests.

\section{Authors' contributions}

DJP, carried out project approach, study design, analysis of results, field work and preparation of the manuscript. EHP, participated in the field work and preparation of the manuscript. MIO, participated in the analysis of results and preparation of the manuscript. JDR, carried out the molecular genetic studies, analysis of results and preparation of the manuscript. FG, participated in the analysis of results and preparation of the manuscript. JM, carried out project approach, study design, analysis of results, field work and preparation of the manuscript. All authors read and approved the final version of the manuscript.

\section{Authors' information}

DJP, MSc. Universidad de los Andes, Bogotá-Colombia. EHP, MSc. Fundación Cataruben, Casanare-Bogotá, Colombia $\mathrm{MIO}, \mathrm{PhD}$. Investigator, Universidad de los Andes, Bogotá-Colombia. JDR, PhD. Principal Professor, Universidad del Rosario, Bogotá-Colombia. FG, Emeritus Professor, Universidad de los Andes, Bogotá-Colombia. JM, Dr. rer. nat. Associate Professor, Universidad de los Andes, BogotáColombia.

\section{Acknowledgements}

Financial support was obtained from Colciencias Project No. 1204-459-21479 "Aspectos de ecología sensorial que contribuyen a la transmission vectorial de la enfermedad de Chagas en Colombia", the Universidad de Los Andes' Science Faculty's Research Fund and The European Union Seventh Framework Programme, Contract number 223034 (Chagas EpiNet). We would like to thank Yasmin Medina for all her assistance during the fieldwork.

\section{Author details}

${ }^{1}$ Centro de Investigaciones en Microbiología y Parasitología Tropical (CIMPAT), Departamento de Ciencias Biológicas, Universidad de los Andes, Bogotá, Colombia. ²Fundación Cataruben, Casanare-Bogotá, Colombia. ${ }^{3}$ Grupo de Investigaciones Microbiológicas Universidad del Rosario (GIMUR), Facultad de Ciencias Naturales y Matemáticas, Universidad del Rosario, Bogotá, Colombia. ${ }^{4}$ Facultad de Ciencias, Universidad de los Andes, A.A. 4976 Carrera 1a \# 18A-10, Bogotá, Colombia.

Received: 12 September 2015 Accepted: 11 November 2015 Published online: 19 November 2015

\section{References}

1. World Health Organization, UNICEF/UNDP/World Bank/WHO Special Programme for Research and Training in Tropical Diseases and Pan American Health Organization. TDR Reporte sobre la enfermedad de 
Chagas. Grupo de trabajo científico. TDR/SWG/09. Geneva: World Health Organization; 2009. http://apps.who.int/iris/handle/10665/69724.

2. Rassi Jr A, Rassi A, Marin-Neto JA. Chagas Disease. Lancet. 2010;375:1388-402.

3. Zingales M, Miles MA, Campbell DA, Tibayrenc M, Macedo AM, Texeira MM, et al. The revised Trypanosoma cruzi subspecific nomenclature: Rationale, epidemiological relevance and research applications. Infect Genet Evol. 2012;12:240-53.

4. Lent $H$, Wydgodzinsky P. Revision of the Triatominae (Hemiptera, Reduviidae), and their significance as vectors of Chagas disease. Bull Amer Mus Nat Hist. 1979;163:123-520.

5. Guhl F, Aguilera G, Pinto N, Vergara D. Actualización de la distribución geográfica y ecoepidemiología de la fauna de triatominos (Reduviidae: Triatominae) en Colombia. Biomédica. 2007;27 Suppl 1:143-62.

6. Moncayo A, Ortiz MI. An update on Chagas disease (human American trypanosomiasis). Ann Trop Med Parasitol. 2006;8:663-7.

7. Hashimoto K, Schofield CJ. Elimination of Rhodnius prolixus in Central America. Parasit Vectors. 2012;5:45. http://www.parasitesandvectors.com/ content/5/1/45.

8. Cecere MC, Vazquez-Prokopec GM, Gürtler RE, Kitron U. Spatio-temporal analysis of reinfestation by Triatoma infestans (Hemiptera:Reduviidae) following insecticide spraying in a rural community in northwestern Argentina. Am J Trop Med Hyg. 2004;71:803-10.

9. Dumonteil E, Ruiz-Piña H, Rodriguez-Félix E, Barrera-Pérez M, Ramirez-Sierra MJ, Rabinovich JE, et al. Re-infestation of houses by Triatoma dimidiata after intradomicile insecticide application in the Yucatán Peninsula, Mexico. Mem Inst Oswaldo Cruz. 2004;99:253-6.

10. Feliciangeli MD, Sanchez-Martin M, Marrero R, Davies C, Dujardin JP. Morphometric evidence for a possible role of Rhodnius prolixus from palm trees in house re-infestation in the State of Barinas (Venezuela) Acta Trop. 2007;101:169-77.

11. Fitzpatrick S, Feliciangeli MD, Sanchez-Martin MJ, Monteiro FA, Miles MA. Molecular genetics reveal that sylvatic Rhodnius prolixus do colonise rural houses. PLoS Negl Trop Dis. 2008; doi:10.1371/journal.pntd.0000210.

12. Wisnivesky-Colli C, Gürtler RE, Solarz ND, Schweigmann NJ, Pietrokovsky SM, Alberti A, et al. Dispersive flight and house invation by Triatoma guasayana and Triatoma sordida in Argentina. Mem Inst Oswaldo Cruz. 1993;88:27-32.

13. Vazquez-Prokopec GM, Cecere MC, Canale DM, Gürtler RE, Kitron U. Spatiotemporal patterns of reinfestation by Triatoma guasayana (Hemiptera: Reduviidae) in a rural community of Northwestern Argentina. J Med Entomol. 2005:42:571-81

14. Longa A, Scorza JV. Migración de Rhodnius robustus (Hemiptera: Triatominae) desde Acrocomia aculeata (Palmae) hacia domicilios rurales en Venezuela. Bol Mal Salud Amb. 2007:47:213-20.

15. Pinto Dias JC. Southern cone initiative for the elimination of domestic populations of Triatoma infestans and the interruption of transfusional Chagas disease. Historical aspects, present situation, and perspectives. Mem Inst Oswaldo Cruz. 2007:102 Suppl 1:11-8.

16. Sanchez-Martin MJ, Feliciangeli MD, Campbell-Lendrum D, Davies CR. Could the Chagas disease elimination programme in Venezuela be compromised by reinvasion of houses by sylvatic Rhodnius prolixus bug populations? Trop Med Int Health. 2006;11:1585-93.

17. Lehane MJ, Schofield CJ. Flight initiation in Triatoma infestans (Klug) (Hemiptera:Reduviidae). Bull Entomol Res. 1982;72:497-510.

18. McEwen PK. A comparison of the diurnal flight pattern of two triatomine bugs Triatoma infestans and Triatoma sordida (Heteroptera: Reduviidae). Mitt Schweiz Ent Ges. 1994;67:453-5.

19. Galvão C, da Silva RD, Jurberg J, Carcavallo R. Início da Atividade de Vôo em Triatoma infestans (Klug, 1834) e T. melanosoma Martínez, Olmedo \& Carcavallo, 1987 (Hemiptera, Reduviidae). Mem Inst Oswaldo Cruz. 2001:96:137-40.

20. Lehane MJ, Schofield CJ. Field experiments of dispersive flight by Triatoma infestans. Trans R Soc Trop Med Hyg. 1981;3:399-400.

21. Schweigmann N, Vallvé S, Muscio O, Ghillini M, Alberti A, Wisnivesky-Colli C. Dispersal flight by Triatoma infestans in an arid area of Argentina. Med Vet Entomol. 1988;2:401-4

22. Schofield CJ, Lehane MJ, McEwan P, Catalá SS, Gorla DE. Dispersive flight of Triatoma sordida. Trans R Soc Trop Med Hyg. 1991;85:676-8.

23. Schofield CJ, Lehane MJ, McEwen P, Catalá SS, Gorla DE. Dispersive flight by Triatoma infestans under natural climatic conditions in Argentina. Med Vet Entomol. 1992;6:51-6.
24. Vazquez-Prokopec GM, Ceballos LA, Kitron U, Gürtler RE. Active dispersal of natural populations of Triatoma infestans (Hemiptera: Reduviidae) in rural Northwestern Argentina. J Med Entomol. 2004;4:614-21.

25. Richer W, Kengne P, Rojas Cortez M, Perrineau MM, Cohuet A, Fontenille D, et al. Active dispersal by wild Triatoma infestans in the Bolivian Andes. Trop Med Int Health. 2007;12:759-64.

26. Abrahan LB, Gorla DE, Catalá SS. Dispersal of Triatoma infestans and other Triatominae species in the arid Chaco of Argentina - Flying, walking or passive carriage? The importance of walking females. Mem Inst Oswaldo Cruz. 2011;106:232-9.

27. Sjogren RD, Ryckman RE. Epizootiology of Trypanosoma cruzi in southwestern North America. Part VIII: Nocturnal flights of Triatoma protracta (Uhler) as indicated by collection at black light traps. J Med Entomol. 1966;1:81-92.

28. Gomez-Nuñez JC. Resting places, dispersal and survival of $\mathrm{CO}_{60}$-Tagged adult Rhodnius prolixus. J Med Entomol. 1969;6:83-6.

29. Tonn RJ, Espinola H, Mora E, Jimenez JE. Trampa de luz negra como método de captura nocturna de triatomines en Venezuela. Bol Dir Malariol y San Amb. 1978;18:25-30

30. Ekkens DB. Nocturnal flights of Triatoma (Hemiptera:Reduviidae) in Sabino Canyon, Arizona. J Med Entomol. 1981;3:211-27.

31. Minoli SA, Lazzari CR. Take-off activity and orientation of triatomines (Heteroptera: Reduviidae) in relation to the presence of artificial lights. Acta Trop. 2006;97:324-30.

32. de la Fuente AL C, Minoli SA, Lopes CM, Noireau F, Lazzari CR, Lorenzo MG Flight dispersal of the Chagas disease vectors Triatoma brasiliensis and Triatoma pseudomaculata in northeastern Brazil. Acta Trop. 2007;101:115-9.

33. Castro MCM, Barrett TV, Santos WS, Abad-Franch F, Rafael JA. Attraction of Chagas disease vectors (Triatominae) to artificial light sources in the canopy of primary Amazon rainforest. Mem Inst Oswaldo Cruz. 2010;105:1061-4.

34. Lehane MJ, McEwen PK, Whitaker CJ, Schofield CJ. The role of temperature and nutritional status in flight initiation by Triatoma infestans. Acta Trop. 1992:52:27-38.

35. McEwen PK, Lehane MJ. The effect of varying feed interval on nymph development, subsequent adult flight behaviour, and autogeny in the triatomine bug Triatoma infestans (Klug) (Hem., Reduviidae). J Appl Entomol. 1993:115:90-6.

36. McEwen PK, Lehane MJ. Factors influencing flight initiation in the triatomine bug Triatoma sordida (Hemiptera: Rediviidae). Insect Sci Appl. 1993:4:461-4.

37. Noireau F, Dujardin JP. Flight and nutritional status of sylvatic Triatoma sordida and Triatoma guasayana. Mem Inst Oswaldo Cruz. 2001;3:385-9.

38. Ceballos LA, Vazquez-Prokopec GM, Cecere MC, Marcet PL, Gürtler RE. Feeding rates, nutritional status and flight dispersal potential of peridomestic populations of Triatoma infestans in rural Northwestern Argentina. Acta Trop. 2005;95:149-59.

39. Gurevitz JM, Ceballos LA, Kitron U, Gürtler RE. Flight initiation of Triatoma infestans (Hemiptera: Reduviidae) under natural climatic conditions. J Med Entomol. 2006;43:143-50

40. Gurevitz JM, Kitron U, Gürtler RE. Flight muscle dimorphism and heterogeneity in flight initiation of field-collected Triatoma infestans (Hemiptera: Reduviidae). J Med Entomol. 2007:44:186-91.

41. Angulo VM, Esteban L, Luna KP. Attalea butyracea próximas a las viviendas como posible fuente de infestación domiciliaria por Rhodnius prolixus (Hemiptera: Reduviidae) en los Llanos Orientales de Colombia. Biomédica. 2012;32:277-85.

42. Salazar FR, Trujillo ML, Escobar MC. Prevalence of Trypanosoma cruzi infection among people aged 15 to 89 years inhabiting the Deparment of Casanare (Colombia). PLoS Negl Trop Dis. 2015; doi:10.1371/journal. pntd.0002113

43. Angulo VM, Esteban L. Nueva trampa para la captura de triatominos en habitats silvestres y peridomésticos. Biomédica. 2011;31:264-7.

44. Urbano P, Poveda C, Molina J. Effect of the physionogmy of Attalea Butyracea (Arecoideae) on population density and age distribution of Rhodnius prolixus (Triatomianae). Parasit Vectors. 2015;8:199. http://www. parasitesandvectors.com/content/8/1/199.

45. Monteiro FA, Barret TV, Fitzpatrick S, Cordon-Rosales C, Feliciangeli D, Beard CB. Molecular phylogeography of the Amazonian Chagas disease vectors Rhodnius prolixus and R. robustus. Mol Ecol. 2003;12:997-1006.

46. Ramírez JD, Guhl F, Messenger LA, Lewis MD, Montilla M, Cucunuba Z, et al. Contemporary cryptic sexuality in Trypanosoma cruzi. Mol Ecol. 2012; $17: 4216-26$.

47. Zar JH. Biostatistical Analysis. New Jersey: Prentice Hall; 1999.

48. Batschelet E. Circular statistics in biology. London: Academic; 1999. 
49. Rendon LM, Guhl F, Cordovez JM, Erazo D. New scenarios of Trypanosoma cruzi transmission in the Orinoco region of Colombia. Mem Inst Oswaldo Cruz. 2015;110:283-8.

50. Cordovez JM, Guhl F. The impact of landscape transformation on the reinfestation rates of Rhodnius prolixus in the Orinoco Region, Colombia. Acta Trop. 2015;151:73-9.

51. Marcili A, Lima L, Valente VC, Valente SA, Batista JS, Junqueira AC, et al. Comparative phylogeography of Trypanosoma cruzi TCllc: New hosts, association with terrestrial ecotopes and spatial clustering. Inf Gen Evol. 2009;9:1265-74.

52. Ocaña-Mayorga S, Llewellyn MS, Costales JA, Miles MA, Grijalva MJ. Sex, subdivision, and domestic dispersal of Trypanosoma cruzi lineage I in Southern Ecuador. PLoS Negl Trop Dis. 2010; doi:10.1371/journal. pntd.0000915.

53. Wolff M, Castillo D. Evidencias de domesticación y aspectos biológicos de Panstrongylus geniculatus (Latreille, 1811) (Hemiptera: Reduviidae). Acta Entomol Chil. 2000:24:77-83.

54. Reyes-Lugo M, Rodriguez-Acosta A. Domiciliation of the sylvatic Chagas disease vector Panstrongylus geniculatus Latreille, 1811 (Triatominae: Reduviidae) in Venezuela. Trans R Soc Trop Med Hyg. 2000;94:508.

55. Ramírez JD, Duque MC, Montilla M, Cucunuba ZM, Guhl F. Multilocus PCR RFLP profiling in Trypanosoma cruzi I highlights an intraspecific genetic variation pattern. Infect Genet Evol. 2012;12:1743-50.

56. Burgos JM, Diez M, Vigliano C, Bisio M, Risso M, Duffy T, et al. Molecular identification of Trypanosoma cruzi discrete typing units in end-stage chronic Chagas heart disease and reactivation after heart transplantation. Clin Infect Dis. 2010;51:485-95.

57. Ramírez JD, Guhl F, Rendon LM, Rosas F, Marin-Neto JA, Morillo CA. Chagas cardiomyopathy manifestations and Trypanosoma cruzi genotypes circulating in chronic chagasic patients. PLoS Negl Trop Dis. 2010; doi:10.1371/journal.pntd.0000899.

58. Carrasco HJ, Segovia M, Llewellyn MS, Morocoima A, Urdaneta-Morales S, Martinez C, et al. Geographical distribution of Trypanosoma cruzi genotypes in Venezuela. PLoS Negl Trop Dis. 2012; doi:10.1371/journal.pntd.0001707.

59. Llewellyn MS, Lewis MD, Acosta N, Yeo M, Carrasco HJ, Segovia M, et al. Trypanosoma cruzi llc: Phylogenetic and phylogeographic insights from sequence and microsatellite analysis and potential impact on emergent Chagas disease. PLoS Negl Trop Dis. 2009; doi:10.1371/journal.pntd.0000510.

60. Llewellyn MS, Miles MA, Carrasco HJ, Lewis MD, Yeo M, Vargas J, et al. Genome-scale multilocus microsatellite typing of Trypanosoma cruzi discrete typing unit I reveals phylogeographic structure and specific genotypes linked to human infection. PLoS Pathog. 2009; doi:10.1371/journal.ppat.1000410.

61. Guhl F, Pinto N, Aguilera G. Sylvatic Triatominae: a new challenge in vector control transmission. Mem Inst Oswaldo Cruz. 2009;104 Suppl 1:71-5.

62. Escalante ME, Gomez D, Silvera LA, Sanchez G, Venegas J. Detection of high percentage of Trypanosoma cruzi infection, the etiological agent of Chagas disease, in wild populations of Colombian caribbean triatomines. Acta Parasitol. 2015;60:315-21.

63. Cantillo-Barraza O, Chaverra D, Marcet P, Arboleda-Sanchez S, Triana-Chavez O. Trypanosoma cruzi transmission in a Colombian caribbean region suggests that secondary vectors play an important epidemiological role. Parasit Vectors. 2014;7:381. http://www.parasitesandvectors.com/content/7/1/381.

64. Cantillo-Barraza O, Garces E, Gomez-Palacio A, Cortes LA, Pereira A, Marcet $\mathrm{PL}$, et al. Eco-epidemiological study of an endemic Chagas disease region in northern Colombia reveals the importance of Triatoma maculata (Hemiptera: Reduviidae), dogs, and Didelphis marsupialis in Trypanosoma cruzi maintenance. Parasit Vectors. 2015;8:482. http://www. parasitesandvectors.com/content/8/1/482.

\section{Submit your next manuscript to BioMed Central and take full advantage of:}

- Convenient online submission

- Thorough peer review

- No space constraints or color figure charges

- Immediate publication on acceptance

- Inclusion in PubMed, CAS, Scopus and Google Scholar

- Research which is freely available for redistribution

Submit your manuscript at www.biomedcentral.com/submit 